\title{
METHODOLOGICAL APPROACHES TO THE CREATION OF THE INDICES FOR A COMPREHENSIVE ASSESSMENT OF THE HEALTH STATE OF THE POPULATION AND IIS PROVISION OF MEDICAL CARE
}

Chorna V.V., Dotsenko V.M., Makhniuk V.M., Mogilny S.M., Ocheretiana G.V. МЕТОДИЧНІ ПІДХОДИ ДО СТВОРЕННЯ ПНДЕКСІВ ДЛЯ КОМПЛЕКСНӦ̈
ОЦПНКИ СТАНУ ЗДОРОВ'Я НАСЕЛЕННЯ ТА ЗАБЕЗПЕЧЕНОСТІ ЙОГО
МЕДИЧНОЮ ДОПОМОГОЮ

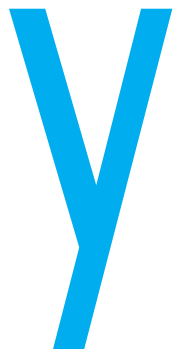

14OРНA B.B. 2ДОЦЕНКО В.М., 2МАХНЮК В.М., 2МОГИЛЬНИЙ С.М.,

2ОЧЕРЕТЯНА Г.В

1Вінницький національний медичний університет

ім. М.І. Пирогова,

м. Вінниця, Україна

2ДУ «Інститут громадського здоров'я ім. О.М. Марзєєва НАМН України», м. Київ статті описано методичні підходи до створення інтегральних індексів людського здоров'я (ІЛЗ) та медичного забезпечення населення (IMЗН), за допомогою яких можна здійснювати узагальнену (інтегральну, комплексну) оцінку стану здоров'я населення України на основі показників смертності, інвалідності та захворюваності, а також забезпеченості населення медичною допомогою на основі показників забезпеченості населення лікарями, середнім медперсоналом та ліжками на рівні окремих регіонів чи країн.

Актуальність дослідження і постановка проблеми. Необхідність створення інтегральних індексів здоров'я та медичного забезпечення населення викликана певними причинами.

Як відомо, індексний аналіз широко застосовується в усіх сферах людської діяльності - в економіці, торгівлі, промисловості, транспорті тощо. У статистичних посібниках йому присвячуються цілі розділи.

Нагадаємо, що індекс - це статистичний відносний показник, що виражає співвідношення рівня даного явища та його рівня у минулому (динамічний індекс) або у просторі (територіальний індекс), або рівня аналогічного явища, прийнятому як базовий (основа). Індекси розподіляються на індивідуальні, групові і загальні (агрегатні). Групові і загальні індекси отримують 3 індивідуальних за спеціальними математикостатистичними формулами [1-3].

Найширше застосовуються у різних сферах народного господарства індивідуальні індекси. Значно меншого застосування отримали групові та загальні індекси. Щодо застосування групових або загальних індексів для ком-
МЕТОДИЧНІ ПІДХОДИ ДО СТВОРЕННЯ ІНДЕКСІВ ДЛЯ КОМПЛЕКСНОЇ ОЦІНКИ СТАНУ ЗДОРОВ'Я НАСЕЛЕННЯ

ТА ЙОГО ЗАБЕЗПЕЧЕНОСТІ МЕДИЧНОЮ ДОПОМОГОЮ

1 Чорна В.В., 2 Доценко В.М., 2Махнюк В.М., 2 Могильний С.М., 2Очеретяна Г. В.

${ }^{1}$ Вінницький національний медичний університет ім. М.І. Пирогова,

м. Вінниця, Україна

2ДУ «/нститут громадського здоров'я ім. О.М. Марзєєва НАМН України», м. Київ

Мета роботи: розробка та апробація розрахунку індексу людського здоров'я (ІЛЗ) та індексу медичного забезпечення населення (IMЗН) для комплексної оцінки стану здоров'я населення, які б оптимальним чином агрегували показники захворюваності, інвалідності та смертності населення.

Матеріали дослідження: для визначення ІЛЗ та ІМЗН використовувалися статистичні дані МОЗ України за 2017 рік щодо захворюваності, інвалідності, смертності населення України та рівня забезпечення населення медичною допомогою: лікарями, середнім медичним персоналом та лікарняними ліжками.

Результати. Розроблений у попередній період індекс здоров'я не відповідає вимогам ВООЗ і донині не знайшов застосування у практиці охорони здоров'я. Нами створено ІЛЗ за аналогією з методикою розрахунку індексу людського развитку (ІЛР). Розрахунки показали: чим менший ІЛЗ, тим гіршим слід вважати рівень здоров'я населення, а чим він більший, тим кращим слід вважати рівень здоров'я.

() Чорна В.В., Доценко В.М., Махнюк В.М., Могильний С.М., Очеретяна Г.В. СТАТТЯ, 2021. 
плексної оцінки здоров'я населення, то причини їх створення, на нашу думку, такі.

Як відомо, у повсякденній практиці медичної статистики оцінка стану здоров'я населення здійснюється на основі трьох основних показників здоров'я: смертності, інвалідності та захворюваності. Ці показники теж $є$ індивідуальними індексами, які відображають нездоров'я населення. Показниками здоров'я вони називаються умовно. У медичній статистиці істинний індивідуальний індекс здоров'я існує давно. Це - співвідношення кількості осіб, що не хворіли, та населення загалом, а також фізичний розвиток населення. Але вони застосовуються переважно у педіатрії. За вище згаданими показниками за кожним окремо порівнюються різні групи населення у розрізі різних адміністративних територій чи факторів ризику і залежно від їхнього рівня робляться позитивні чи негативні висновки про стан здоров'я населення та його фактори ризику $[4,5]$. Ця традиційна методика, яка існує багато десятиліть, не підлягає запереченню. Вона існуватиме й надалі, оскільки ці показники відображають різні стани здоров'я населення.

Але ж у порівняльній практиці можуть виникати різні ситуації. В одній порівняльній групі може бути високий рівень смертності і низькі рівні інвалідності чи захворюваності. I навпаки, в іншій порівняльній групі смертність може бути низькою, а інвалідність чи захворюваність високими. За такої ситуації практично неможливо дати об'єктивну узагальнену оцінку за окремими показниками стану здоров'я того чи іншого населення, що порівнюється.

Таку оцінку можна дати за допомогою створення інтегрального індексу здоров'я на основі показників смертності, інвалідності та захворюваності. Так вважають й інші автори $[6,7]$.

Слід підкреслити, що проблема створення узагальнених критеріїв здоров'я населення, які б оптимальним чином агрегували початкову інформацію, представлену великою кількістю медикодемографічних показників захворюваності, інвалідності та смертності населення, як зазначається у роботі [8], давно перебуває у центрі уваги фахівців. У цьому літературному джерелі детально розглядаються різні підходи до створення інтегральних індексів здоров'я. Ми їх не будемо наводити, бо вони дуже складні для застосування. Наведемо лише викладені у цьому джерелі сформовані ще 1971 року Всесвітньою організацією охорони здо- ров'я вимоги до узагальненого індексу здоров'я населення, які необхідні для обґрунтованого застосування останнього як критерію для порівняння великих сукупностей населення та оцінки ефективності програм охорони здоров'я.

Це такі вимоги:

$\square$ Доступність даних. Існування можливості для отримання необхідних даних без складних спеціальних досліджень.

$\square$ Повнота охоплення. IHдекс має бути отриманим 3 даних, що охоплюють населення, для якого він призначається.

$\square$ Якість. Національні дані не мають змінюватись у часі та просторі.

$\square$ Універсальність. Індекс за можливістю має висвітлювати фактори, які впливають на рівень здоров'я.

О Обчислюваність. Індекс має розраховуватися найпростішим способом, а розрахунок не бути вартісним.

$\square$ Прийнятність. Індекс має бути прийнятним і, беззаперечно, мають існувати прийнятні методи для розрахунку індексу і його інтерпретації.

口 Відтворюваність. Під час використання індексу здоров'я різними спеціалістами, за різних умов і у різні часи результати мають бути ідентичними.

口 Специфічність. Індекс має
Розрахувавши середню величину індексу 0,603 та 0,117, ми 3'ясували: середні величини індексу лежать у межах

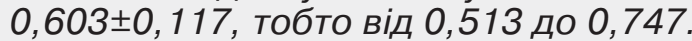
Величини нижче 0,513 вважаються низькими, а вище 0,747 - високими індексами людського здоров'я. Розподіл областей України за величиною ІЛР показав, що групу з добрим здоров'ям склали 4 області з середнім ІЛЗ, який дорівнює 0,800. До групи з задовільним здоров'ям увійшли 15 областей з середнім ІЛЗ, який дорівнює 0,635, а до групи з незадовільним здоров'ям - 3 області з середнім ІЛЗ, який дорівнює 0,453. Середні групові величини індексу медичного забезпечення населення становили у групі областей з добрим здоров'ям 0,601, з задовільним здоров'ям населення - 0,513, з незадовільним 0,562. Дисперсійний аналіз показав, що ці величини між собою суттєво не відріз- няються $(F=0,56 ; p>0,05)$, тому всі групи населення областей з різним рівнем здоров'я мають приблизно однаковий рівень забезпечення медичною допомогою.

Висновки. Результати аналізу з використанням необхідних методів математичноі статистики дозволяють стверджувати: запропоновані інтегральні індекси людського здоров'я та медичного забезпечення населення адекватно відбивають реальну ситуацію, прості у застосуванні, і їх можна рекомендувати для використання у практиці медичної статистики на рівні МОЗ і ВООЗ. За їхньою допомогою можна порівнювати рівень здоров'я населення та його забезпечення медичною допомогою у розрізі окремих регіонів або країн.

\section{Ключові слова: індекс людського здоров'я, медичне забезпечення, здоров'я населення.}


відображати зміни лише у тих явищах, відображенням яких він служить.

口 Чутливість. Індекс має бути чутливим до змін відповідних явищ.

口 Валідність. Індекс має бути істинним виразом показників, мірилом яких він є. Має бути створеною якась форма незалежного і зовнішнього доказу цього індексу.

口 Репрезентативність. Індекс має бути представницьким під час відображення змін у здоров'ї окремих статевовікових та інших виділених органом управління контингентів населення.

$\square$ Ієрархічність. Індекс має складатися за єдиним принципом для різних ієрархічних рівнів, які виділяють і охоплюють сукупності населення для врахованих захворювань, їхніх стадій і наслідків. Має існувати можливість його уніфікованого згортання і розгортання за складовими компонентами.

口 Стан мети. Індекс здоров'я має адекватно відображати мету поліпшення здоров'я і стимулювати суспільство до пошуку найбільш ефективних шляхів досягнення цієї мети.

Як бачимо, ще з тих часів вимоги ВООЗ до індексу здоров'я були дуже жорсткими. Можливо, створені на той час різними авторами індекси здоров'я не відповідали цим вимогам, і ця ідея ВООЗ не знайшла свого втілення у практиці охорони здоров'я всупереч тому, як це відбулося з індексом людського розвитку, яким користується світова практика вже протягом багатьох десятиліть.

Мета даної роботи полягає у розробці та апробації розрахунку індексу людського здоров'я (ІЛЗ) та індексу медичного забезпечення населення (IM3H) для узагальнення критеріїв комплексної оцінки стану здоров'я населення України, які б оптимальним чином агрегували показники захворюваності, інвалідності та смертності населення.
Матеріали та методи. Матеріалами досліджень були статистичні данні із довідника МО3 України за 2017 рік щодо захворюваності, інвалідності, смертності населення України і рівень забезпечення населення медичною допомогою, а саме: забезпеченість лікарями, середніми медичними працівниками та ліжками у стаціонарі для визначення індексу людського здоров'я та індексу медичного забезпечення населення Ук-

раїни. У роботі використані методи математичної статистики, зокрема дисперсійний метод аналізу, кореляційний метод тощо.

Запропонована нами методика розрахунку індексу людського здоров'я (ІЛЗ) повністю відрізняється від раніше розроблених дуже складних методів. Наш індекс людського здоров'я (ІЛЗ) створено за аналогією 3 методикою розрахунку індексу людського розвитку (ІЛР),

Таблиця 1

Результати розрахунку індексу людського здоров'я в Україні за 2017 рік у розрізі окремих областей України

\begin{tabular}{|c|c|c|c|c|c|c|c|}
\hline \multirow[b]{2}{*}{ Область } & \multicolumn{2}{|c|}{$\begin{array}{c}\text { Первинна } \\
\text { захворюва- } \\
\text { ність, \%оо }\end{array}$} & \multicolumn{2}{|c|}{$\begin{array}{c}\text { Смертність, } \\
\% о о\end{array}$} & \multicolumn{2}{|c|}{$\begin{array}{c}\text { Первинна } \\
\text { інвалідність, } \\
\text { \%оо }\end{array}$} & \multirow{2}{*}{ 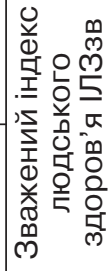 } \\
\hline & 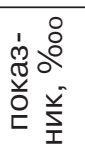 & $\begin{array}{l}\text { m } \\
0 \\
\text { d } \\
\text { I } \\
\text { I }\end{array}$ & 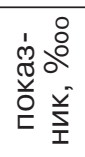 & $\begin{array}{l}\bar{u} \\
0 \\
\text { d } \\
\underline{\square} \\
\text { I }\end{array}$ & 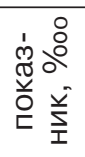 & $\begin{array}{l}\dot{\bar{U}} \\
\dot{v} \\
\bar{D} \\
\underline{\underline{I}}\end{array}$ & \\
\hline АР Крим & - & - & - & - & - & - & - \\
\hline Вінницька & 651 & 0,622 & 241 & 0,295 & 50 & 0,500 & 0,519 \\
\hline Волинська & 685 & 0,537 & 135 & 0,825 & 41 & 0,725 & 0,679 \\
\hline Дніпропетровська & 891 & 0,022 & 165 & 0,675 & 38 & 0,800 & 0,515 \\
\hline Донецька & - & - & - & - & - & - & - \\
\hline Житомирська & 641 & 0,647 & 200 & 0,500 & 43 & 0,675 & 0,613 \\
\hline Закарпатська & 588 & 0,780 & 150 & 0,750 & 39 & 0,775 & 0,770 \\
\hline Запорізька & 587 & 0,782 & 277 & 0,115 & 50 & 0,500 & 0,600 \\
\hline Івано-Франківська & 848 & 0,130 & 173 & 0,635 & 42 & 0,700 & 0,477 \\
\hline Київська & 769 & 0,327 & 274 & 0,130 & 45 & 0,625 & 0,370 \\
\hline Кіровоградська & 641 & 0,647 & 156 & 0,720 & 42 & 0,700 & 0,680 \\
\hline Луганська & - & - & - & - & - & - & - \\
\hline Львівська & 770 & 0,325 & 128 & 0,860 & 62 & 0,200 & 0,532 \\
\hline Миколаївська & 663 & 0,592 & 170 & 0,650 & 44 & 0,650 & 0,622 \\
\hline Одеська & 682 & 0,545 & 141 & 0,795 & 42 & 0,700 & 0,660 \\
\hline Полтавська & 547 & 0,882 & 234 & 0,330 & 46 & 0,600 & 0,702 \\
\hline Рівненська & 753 & 0,367 & 147 & 0,785 & 41 & 0,725 & 0,600 \\
\hline Сумська & 532 & 0,920 & 176 & 0,620 & 37 & 0,825 & 0,821 \\
\hline Тернопільська & 687 & 0,532 & 148 & 0,760 & 42 & 0,700 & 0,642 \\
\hline Харківська & 664 & 0,590 & 157 & 0,715 & 36 & 0,850 & 0,705 \\
\hline Херсонська & 541 & 0,897 & 159 & 0,705 & 37 & 0,825 & 0,829 \\
\hline Хмельницька & 639 & 0,652 & 196 & 0,520 & 49 & 0,525 & 0,590 \\
\hline Черкаська & 651 & 0,622 & 200 & 0,500 & 35 & 0,875 & 0,649 \\
\hline Чернівецька & 633 & 0,667 & 112 & 0,940 & 39 & 0,775 & 0,780 \\
\hline Чернігівська & 730 & 0,425 & 189 & 0,555 & 45 & 0,625 & 0,511 \\
\hline \multicolumn{8}{|c|}{ Фіксовані показники } \\
\hline Мінімальні & 500 & - & 100 & - & 30 & - & - \\
\hline Максимальні & 900 & - & 300 & - & 70 & - & - \\
\hline Їхня різниця & 400 & - & 200 & - & 40 & - & - \\
\hline Коефіцієнт ваги (К) & 0,2 & - & 0,5 & - & 0,3 & - & - \\
\hline
\end{tabular}

№ 12021 Rnurovmat \& IIrauri! 22 
METHODOLOGICAL APPROACHES

TO THE CREATION OF THE INDICES

FOR A COMPREHENSIVE ASSESSMENT

OF THE HEALTH STATE OF THE POPULATION

AND ITS PROVISION OF MEDICAL CARE

1 Chorna V.V., ${ }^{2}$ Dotsenko V.M.,

2Makhniuk V.M., ${ }^{2}$ Mohilnyi S.M.,

2Ocheretiana H.V.

1 National Pirogov Memorial Medical University, Vinnitsa

${ }^{2}$ State Institution «O.M. Marzieiev Institute for Public Health of the National Academy of Medical Sciences of Ukraine», Kyiv

Objective: We developed and evaluated the calculation of the human health index $(\mathrm{HHI})$ and the index of the medical provision of the population (IMPP) for a comprehensive assessment of the health state of the population, which would optimally aggregate the indicators of morbidity, disability, and mortality of the population.

Materials and methods: In the study, we used the statistical data from the reference book of the Ministry of Health of Ukraine for 2017 on the incidence, disability, mortality of the population of Ukraine and the level of the provision of the medical care of the population, namely, the provision of doctors, nurses, and beds in the hospital to determine the human health index and the index of medical provision of the population of Ukraine. Results: The health index, developed by various authors, did not meet the requirements of the WHO and it has not found its application in healthcare practice yet. The Human Health Index (HHI) has been created by us by analogy with the methodology for the calculation of the Human
Development Index (HDI). The calculations show that the lower the human health index, the health level of the population should be considered the worst, and the higher it is, the health level should be considered the best. Having calculated the average value of the index 0.603 and 0.117 , we found that the average values of the index lie in the range of $0.603 \pm 0.117$, i.e., from 0.513 to 0.747 . Values below 0.513 are considered low, and above 0.747 - high indices of human health. The average group values of the index of the medical provision of the population in the group of regions with a good health of the population were 0.601 , with a satisfactory health -0.515 , with unsatisfactory health -0.562 . Analysis of variance showed that these values did not differ significantly from each other $(F=0.56 ; p>0.05)$. Therefore, all groups of the population in the regions with different health levels have approximately the same level of medical care provision. Conclusions: The above results of the analysis using the necessary methods of mathematical statistics are a cause to assert that the proposed integral indices of human health and medical provision of the population, which adequately reflect the reality and simplicity of the application, can be recommended for the use in the practice of medical statistics both at the level of the Ministry of Health and at the level of the WHO. The level of the health of the population and its provision with medical care in the context of separate regions or countries can be compared with their help.

Keywords: human health index, medical care, health of the population. яку викладено у [9]. По суті, наш ІЛЗ є прообразом ІЛР. Як і ІЛР, ІЛЗ розраховується на основі кількох показників, але здоров'я: смертності, первинної інвалідності та первинної захворюваності.

Спочатку для кожного показника розраховується індивідуальний індекс. Для розрахунку цього індексу встановлюються мінімальні і максимальні значення показника здоров'я. Вони визначаються експертами шляхом опитування або за допомогою сигмального методу оцінки, за якого мінімальні величини становлять $\bar{X}-1 \delta$ і менше, а максимальні $-\bar{X}+1 \delta$ і більше [10]. Але вони мають бути вищими чи нижчими за фактичні показники, щоб у різниці не отримувати «0» або від'ємне число. Ці фіксовані показники наводяться у наведених таблицях.

Індивідуальні індекси для кожного показника здоров'я

розраховуються за формулою 1 , взятою із [9]:

$I_{\text {iнд. }}=\frac{\text { фактичне значення } P \text { - мінімальне значення } P_{1}}{\text { максимальне значення } P_{2}-\text { мінімальне значення } P_{1}}$

де $\mathrm{P}$ - фактичний показник здоров'я; $\mathrm{P}_{1}$ і $\mathrm{P}_{2}$ - фіксовані мінімальний і максимальний показники здоров'я.

Як відомо, ця формула призначена для нормування показників стабілізаторів чим більше їхнє значення, тим краще. Тому за цією формулою розраховано індиві-

$I_{\text {інд. }}=\frac{\text { максимальне значення } P_{2}-\text { фактичне значення } P}{\text { максимальне значення } P_{2}-\text { мінімальне значення } P_{1}}$

дуальні індекси для ІМЗН, який відповідає цим умовам. У нашому випадку нормуються показники смертності, захворюваності, інвалідності - чим вищі їхні значення, тим стан суспільного здоров'я гірший, тому тут доцільно використовувати зворотню фактичного значення, а у знаменнику - різниця максимального та мінімального значення. Тоді чим більшим буде значення індексу, тим кращим вважатиметься здоров'я населення.

Цю формулу (2) наведено нижче. За нею розраховано індивідуальні індекси для ІЛЗ:

На основі цих індивідуальних індексів і розраховуються узагальнені (інтегральні) індекси: індекс людського здоров'я (ІЛЗ) та індекс медичного забезпечення населення (IM3H). При цьому кожному з показників, за нашою ініціативою, присвоюється коефіцієнт ваги

\section{Envirovinevi \& Ile:urn № 12021}


(значимості, ціни) окремих показників під час оцінки стану здоров'я та рівні медичного забезпечення населення. Розраховуючи ІЛЗ, ми вважали, що найбільшу незворотну шкоду здоров'ю завдає смерть, меншу - інвалідність, ще меншу - захворюваність.

Розподіл областей України за 2017 рік за станом здоров'я населення за величиною ІЛЗ та за даними про частку літніх осіб і рівень забезпечення населення медичною допомогою

\begin{tabular}{|c|c|c|c|c|c|}
\hline \multirow[b]{2}{*}{ Область } & \multirow[b]{2}{*}{$\begin{array}{c}\text { Індекс } \\
\text { людського } \\
\text { здоров‘я }\end{array}$} & \multirow{2}{*}{$\begin{array}{c}\text { Відсоток } \\
\text { до всього } \\
\text { населення } \\
\text { осіб віком } \\
65 \text { років } \\
\text { і старше }\end{array}$} & \multicolumn{3}{|c|}{$\begin{array}{c}\text { Забезпеченість, } \\
\text { на } 100 \text { тис. населення }\end{array}$} \\
\hline & & & $\begin{array}{l}\text { ліка- } \\
\text { рями }\end{array}$ & $\begin{array}{c}\text { середнім } \\
\text { мед. } \\
\text { персо- } \\
\text { налом }\end{array}$ & $\begin{array}{l}\text { ліж- } \\
\text { ками }\end{array}$ \\
\hline \multicolumn{6}{|c|}{ І. Хороше здоров'я (ІЛЗ >0,747) } \\
\hline Закарпатська & 0,770 & 11,6 & 388 & 825 & 678 \\
\hline Херсонська & 0,829 & 15,4 & 360 & 847 & 764 \\
\hline Чернівецька & 0,780 & 14,0 & 601 & 987 & 732 \\
\hline Сумська & 0,821 & 17,5 & 408 & 1042 & 820 \\
\hline Загалом & 3,2 & 58,5 & 1757 & 3701 & 2994 \\
\hline У середньому & 0,800 & 44,6 & 439,2 & 925,2 & 748,5 \\
\hline \multicolumn{6}{|c|}{ II. Задовільне здоров'я (ІЛ3 0,514-0,747) } \\
\hline Волинська & 0,673 & 12,9 & 383 & 1001 & 701 \\
\hline Дніпропетровська & 0,515 & 16,5 & 472 & 871 & 875 \\
\hline Житомирська & 0,673 & 16,2 & 379 & 1031 & 686 \\
\hline Вінницька & 0,519 & 17,3 & 491 & 973 & 690 \\
\hline Кіровоградська & 0,670 & 17,7 & 354 & 952 & 850 \\
\hline Львівська & 0,532 & 14,5 & 555 & 1012 & 830 \\
\hline Миколаївська & 0,622 & 15,8 & 339 & 759 & 706 \\
\hline Одеська & 0,660 & 15,2 & 471 & 835 & 779 \\
\hline Полтавська & 0,702 & 17,5 & 487 & 955 & 792 \\
\hline Рівненська & 0,600 & 12,4 & 415 & 1044 & 738 \\
\hline Запорізька & 0,770 & 16,9 & 491 & 902 & 836 \\
\hline Тернопільська & 0,642 & 15,4 & 527 & 1029 & 832 \\
\hline Харківська & 0,705 & 16,4 & 573 & 870 & 837 \\
\hline Хмельницька & 0,590 & 16,7 & 360 & 959 & 787 \\
\hline Черкаська & 0,649 & 18,3 & 386 & 972 & 807 \\
\hline Загалом & 9,522 & 239,7 & 6683 & 14160 & 11746 \\
\hline У середньому & 0,635 & 16,0 & 445,5 & 944 & 783 \\
\hline \multicolumn{6}{|c|}{ III. Незадовільне здоров'я (ІЛЗ <0,513) } \\
\hline Івано-Франківська & 0,477 & 14,0 & 613 & 1057 & 767 \\
\hline Чернігівська & 0,511 & 19,2 & 601 & 1042 & 933 \\
\hline Київська & 0,370 & 15,3 & 417 & 839 & 725 \\
\hline Загалом & 1,358 & 48,5 & 1631 & 2538 & 2425 \\
\hline У середньому & 0,453 & 16,2 & 543,7 & 979,3 & 808,3 \\
\hline $\begin{array}{l}\text { Коефіцієнт } \\
\text { достовірності F }\end{array}$ & 22,52 & 0,92 & 2,51 & 0,25 & 0,68 \\
\hline $\mathrm{p}$ & $<0,01$ & $>0,05$ & $>0,05$ & $>0,05$ & $>0,05$ \\
\hline
\end{tabular}

Визначення запропонованого зваженого індексу людського здоров'я здійснюється за формулою 3:

IЛ $3_{3 B}=\sqrt{K_{C} I^{2}{ }_{C}+K_{i} I^{2}+K_{3} I}{ }^{2}$,(3)

де $1 / 3_{3 в}$ - індекс людського здоров'я зважений;

$K_{C}, K_{i}, K_{3}-$ коефіцієнти ваги показників здоров'я;

$I_{C}, I_{i}, I_{3}-$ індивідуальні індекси показників здоров'я.

За такою формулою розраховувався й ІМЗН.

Результати. Для прикладу, наводиться таблиця 1 з даними для розрахунку комплексного ІЛЗ у розрізі окремих областей України за 2017 рік, взятих із статистичного довідника МОЗ України [11]. Це дані за 22 областями, оскільки за АРК їх немає, а за Донецькою та Луганською областями вони неповні. I ще слід мати на увазі, що ця стаття методичного типу, а не констатації ІЛЗ за конкретний рік. Тому рік, за який взято дані для прикладу, не має значення.

Як випливає з таблиці 1, узагальнений зважений індекс людського здоров'я різний в окремо взятих областях. Так, найменшим він реєструється у Київській області $(0,370)$, а найбільшим - у Херсонський $(0,829)$. Слід мати на увазі, що чим менший індекс людського здоров'я, тим рівень здоров'я населення слід вважати гіршим, а чим він більший, тим здоров'я слід вважати ліпшим.

Але виникає питання, які показники слід вважати низькими, середніми та високими величинами. Це питання ми вирішували за допомогою сигмального методу оцінки. Як відомо, у межах $\bar{X} \pm 1 \delta$ лежить $68 \%$ частот, які вважаються середніми величинами. Величини, менші за $\bar{X}-1 \delta$, вважаються низькими, а більші за $\bar{X}+1 \delta$ - високими величинами [10].

Розрахувавши середню величину індексу за даними таблиці 1 і її $\delta$, які становили 0,630 та 0,117 , отримаємо, що середні величини індексу лежать у межах 0,630 0,117 , тобто від 
МЕТОДИЧЕСКИЕ ПОДХОДЫ К СОЗДАНИЮ ИНДЕКСОВ ДЛЯ КОМПЛЕКСНОЙ ОЦЕНКИ СОСТОЯНИЯ ЗДОРОВЬЯ НАСЕЛЕНИЯ И ЕГО ОБЕСПЕЧЕННОСТИ МЕДИЦИНСКОЙ ПОМОЩЬЮ

1 Черная В.В., 2 Доценко В.М., 2Махнюк В.М., 2 Могильный С.Н., 2Очеретяная А.В.

${ }^{1}$ Винницкий Национальный медицинский университет им. Н.И. Пирогова, Г. Винница, Украина

${ }^{2}$ ДУ «Институт общественного здоровья им. А.Н. Марзеева НАМН Украины», г. Киев, Украина

Цель работы: разработка и апробация расчета индекса человеческого здоровья (ИЧЗ) и индекса медицинского обеспечения населения (ИМОН) для комплексной оценки состояния здоровья населения, которые бы оптимальным образом агрегировали показатели заболеваемости, инвалидности и смертности населения.

Материалы исследования: для определения индекса человеческого здоровья и индекса медицинского обеспечения населения Украины использовались статистические данные Справочника МОЗ Украины за 2017 год по заболеваемости, инвалидности, смертности населения Украины и уровню обеспечения населения медицинской помощью, врачами, средним медицинским персоналом и койками в больнице.

Результаты. Разработанный ранее индекс здоровья не отвечал требованиям ВООЗ и до сих пор не нашел своего применения в практике здравоохранения. Индекс человеческого здоровья (ИЧЗ) создан нами по аналогии с методикой определения индекса человеческого развития (ИЧР). Из расчетов видно, что чем меньше индекс человеческого здоровья, тем уровень здоровья населения следует считать худшим, а чем он больший, тем уровень здоровья следует считать лучшим. Рассчитав среднюю величину индекса 0,603 и 0,117, мы установили, что средние величины индекса лежат в пределах 0,603 0,117 , то есть от 0,513 до 0,747. Величины ниже 0,513 считаются низкими, а выше 0,747 - высокими индексами человеческого здоровья. После распределения областей Украины по величине ИЧР определили, что группу с хорошим здоровьем составили 4 области со средним ИЧЗ, равным 0,800, группу с удовлетворительным здоровьем - 15 областей со средним ИЧЗ, равным 0,635, а в группе с неудовлетворительным здоровьем оказались 3 области со средним ИЧЗ, равным 0,453. Средние групповые величины индекса медицинского обеспечения населения составили в группе областей с хорошим здоровьем населения 0,601, с удовлетворительным - 0,513, с неудовлетворительным здоровьем - 0,562.

Дисперсионный анализ показал, эти величины существенно между собой не отличаются $(F=0,56 ; p>0,05)$. Все группы населения областей с разным уровнем здоровья имеют приблизительно одинаковый уровень обеспечения медицинской помощью.

Выводы. Результаты анализа с использованием необходимых методов математической статистики дают основания утверждать: предложенные интегральные индексы человеческого здоровья и медицинского обеспечения населения адекватно отображают реальность, простоту в применении, и их можно рекомендовать для использования в практике медицинской статистики на уровне МОЗ и ВООЗ. С их помощью можно сравнивать уровень здоровья населения и его обеспечения медицинской помощью в разрезе отдельных регионов или стран.

\section{Ключевые слова: индекс человеческого здоровья, медицинское обеспечение, здоровье населения.}

0,513 до 0,747. Величини $<0,513$, вважаються низькими, а $>0,747$ - високими індексами людського здоров'я.

Таким чином були розподілені області України з таблиці 1 на області з хорошим станом здоров'я (індекси >0,747), задовільним (індекси від 0,514 до 0,747$)$ і незадовільним (індекси <0,513).

Цей розподіл представлено у таблиці 2, в якій також відображено дані про частку літніх осіб як одного з головних факторів ризику для здоров'я та дані про рівень надання населенню медичної допомоги у цих групах областей. Але слід мати на увазі, що ці фактори наведено для прикладу. Той чи інший фахівець на свій розсуд може за таким принципом дослідити інші фактори.

Як бачимо з таблиці 2, найменший індекс людського здоров'я відзначається у групі областей з незадовільним здоров'ям населення, який у середньому становить 0,453. У групі областей 3 задовільним здоров'ям він сягає 0,635, а у групі з хорошим здоров'ям - 0,800. А це означає, що у цій групі стан здоров'я населення на $26,0 \%$ ліпший, ніж у групі областей 3 задовільним здоров'ям і на $76 \%$, ніж у групі областей 3 незадовільним здоров'ям. У групі областей з задовільним здоров'ям рівень здоров'я населення на 40,1\% ліпший, ніж у групі областей з незадовільним здоров'ям. Ця різни- ця статистично значима на рівні 99\% достовірності і більше $(F=22,52 ; p<0,01)$, за даними дисперсійного аналізу.

Щодо результатів розподілу у цих групах областей про частку літніх осіб та забезпечення населення медичною допомогою, то вони такі.

Частка осіб віком 65 років і старші у групі областей з хорошим здоров'ям становила 14,6, у групі областей з задовільним здоров'ям - 16,0\%, а з незадовільним здоров'ям 16,2\%. За даними дисперсійного аналізу, різниця між цими показниками недостовірна ( $p>0,05)$.

Показники забезпеченості населення зазначених вище груп областей лікарями, середнім медперсоналом та

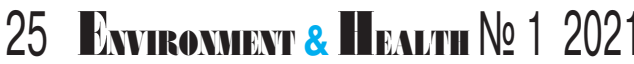


ліжками, як показав той же дисперсійний аналіз, теж статистично не розрізнялися $(p>0,05)$. Тобто усі три зазначені вище групи областей мали приблизно однаковий рівень забезпеченості насета частку літніх осіб.

Медична допомога, зокрема, забезпеченість населення медичною допомогою по своїй суті спрямована на ліклення медичною допомогою

відацію несприятливої дії факторів ризику на здоров'я населення. Але ефективність медичної допомоги не завжди досягає очікуваних результатів за коротший час. Які ж фактори ризику, що спричиняють незадовільне здоров'я у трьох названих у таблиці 2 областях, потребують спеціального дослідження? Наша стаття - методичного плану.

Таблиця 3

\section{Результати розрахунку комплексного зваженого індексу медичного забезпечення населення в окремих областях України, 2017 рік}

\begin{tabular}{|c|c|c|c|c|c|c|c|}
\hline \multirow{3}{*}{ Область } & \multicolumn{6}{|c|}{ Забезпеченість населення, \%оо } & \multirow{3}{*}{ 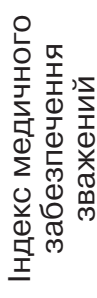 } \\
\hline & \multicolumn{2}{|c|}{ лікарями } & \multicolumn{2}{|c|}{$\begin{array}{c}\text { середнім } \\
\text { медичним } \\
\text { персоналом }\end{array}$} & \multicolumn{2}{|c|}{ ліжками } & \\
\hline & $\begin{array}{c}\text { показ- } \\
\text { ник }\end{array}$ & $\mathrm{I}_{\text {лік }}$ & $\begin{array}{c}\text { показ- } \\
\text { ник }\end{array}$ & $\mathrm{I}_{\mathrm{CM}}$ & $\begin{array}{c}\text { показ- } \\
\text { ник }\end{array}$ & $\mathrm{I}_{\text {лж }}$ & \\
\hline АР Крим & - & - & - & - & - & - & - \\
\hline Вінницька & 491 & 0,477 & 973 & 0,682 & 690 & 0,225 & 0,513 \\
\hline Волинська & 383 & 0,207 & 1001 & 0,752 & 701 & 0,252 & 0,451 \\
\hline Дніпропетровська & 472 & 0,430 & 871 & 0,427 & 875 & 0,687 & 0,491 \\
\hline Донецька & - & - & - & - & - & - & - \\
\hline Житомирська & 379 & 0,197 & 1031 & 0,827 & 686 & 0,215 & 0,483 \\
\hline Закарпатська & 388 & 0,220 & 825 & 0,312 & 678 & 0,199 & 0,247 \\
\hline Запорізька & 491 & 0,477 & 902 & 0,505 & 836 & 0,590 & 0,510 \\
\hline Івано-Франківська & 613 & 0,782 & 1057 & 0,892 & 767 & 0,417 & 0,761 \\
\hline Київська & 417 & 0,292 & 839 & 0,347 & 725 & 0,312 & 0,313 \\
\hline Кіровоградська & 354 & 0,135 & 952 & 0,630 & 850 & 0,625 & 0,454 \\
\hline Луганська & - & - & - & - & - & - & - \\
\hline Львівська & 555 & 0,637 & 1012 & 0,780 & 830 & 0,575 & 0,672 \\
\hline Миколаївська & 339 & 0,097 & 759 & 0,147 & 706 & 0,265 & 0,159 \\
\hline Одеська & 471 & 0,427 & 835 & 0,337 & 779 & 0,447 & 0,406 \\
\hline Полтавська & 487 & 0,467 & 955 & 0,637 & 792 & 0,480 & 0,526 \\
\hline Рівненська & 415 & 0,287 & 1044 & 0,860 & 738 & 0,345 & 0,536 \\
\hline Сумська & 408 & 0,270 & 1042 & 0,855 & 820 & 0,550 & 0,562 \\
\hline Тернопільська & 527 & 0,567 & 1029 & 0,822 & 832 & 0,580 & 0,656 \\
\hline Харківська & 573 & 0,682 & 870 & 0,425 & 837 & 0,592 & 0,876 \\
\hline Херсонська & 360 & 0,150 & 847 & 0,367 & 764 & 0,410 & 0,292 \\
\hline Хмельницька & 439 & 0,347 & 959 & 0,647 & 787 & 0,467 & 0,479 \\
\hline Черкаська & 386 & 0,215 & 972 & 0,680 & 807 & 0,517 & 0,464 \\
\hline Чернівецька & 601 & 0,752 & 987 & 0,717 & 732 & 0,330 & 0,677 \\
\hline Чернігівська & 370 & 0,175 & 1042 & 0,855 & 933 & 0,832 & 0,611 \\
\hline \multicolumn{8}{|c|}{ Фіксовані показники } \\
\hline Мінімальні & 300 & - & 700 & - & 600 & - & - \\
\hline Максимальні & 700 & - & 1100 & - & 1000 & - & - \\
\hline Різниця & 400 & - & 400 & - & 400 & - & - \\
\hline Коефіцієнт К & 0,5 & - & 0,3 & - & 0,2 & - & - \\
\hline
\end{tabular}

Щодо відповідності задекларованого ІЛЗ вимогам ВООЗ, які були наведені вище, то як показало наше співставлення, він цілком або дуже близько відповідає усім вимогам ВООЗ. Але основне - для його визначення існують доступні дані, він дуже просто розраховується і адекватно відображає реальність. До того ж за наведеним вище алгоритмом можна розробити комп'ютерну програму розрахунку цього індексу і визначати його в автоматичному режимі.

На нашу думку, запропонований спосіб визначення ІЛЗ дозволить на різних ієрархічних рівнях оцінювати з високою надійністю узагальнений стан здоров'я населення окремих регіонів країни чи окремих країн.

Таким саме способом розраховується і комплексний індекс забезпеченості населення медичною допомогою. Він визначається на основі даних про забезпеченість населення лікарнями, середнім медперсоналом та лікарняними ліжками. Ці дані у розрізі окремих областей України станом на 2017 рік наведено у таблиці 3.

Створення цього індексу зумовлене тими ж причинами, що і створення індексу людського здоров'я, а саме: за окремими показниками забезпеченості не можна дати загальної оцінки рівня забезпеченості населення медичною допомого, бо в одній області може бути велика чисельність лікарів і мала чисельність середнього медперсоналу чи ліжок, в іншій області, навпаки, велика чисельність ліжок і мала чисельність середнього медперсоналу і лікарів. Застосування інтегральної оцінки рівня медичного забезпечення населення за допомогою зваженого комплексного (інтегрального) індексу медичного забезпечення, що пропонується, виключає таку можливість, бо він об'єднує усі три показники забезпеченості населення меддопомогою, враховуючи 
важливість їхньої дії на оздоровлення хворих. Це здійснюється за допомогою присвоєння кожному показнику, як зазначалося вище, коефіцієнта ваги - важливості дії на оздоровлення хворих. Зрозуміло, що найвищий коефіцієнт ваги надали лікарям - 0.5, потім середньому медперсоналу - 0.3, а лікарняним ліжкам -0.2.

Індивідуальний та інтегральний індекси медичного забезпечення розраховуються за наведеними вище формулами: індивідуальний - за формулою 1, а зважений (інтегральний) індекс - за формулою 3. Результати розрахунку представлено у таблиці 3. Дані для розрахунків взято із Статистичного довідника МО3 України за 2017 рік [11].

Слід мати на увазі, що чим індекс медичного забезпечення населення більший, тим медична забезпеченість краща, і навпаки - чим він менший, тим медична забезпеченість нижча.

Як видно з таблиці 3, 2017 року найменшими зважені індекси медичного забезпечення були у Миколаївській, Закарпатській та Херсонській областях, а найвищими - у Харківській, Івано-Франківській, Чернівецькій, що означає: у першій групі областей рівень медичного забезпечення найнижчий, а у другій найвищий.

Для визначення рівня медичного забезпечення населення з різним станом здоров'я (таблиця 2) індекс медичного забезпечення був розподілений нами між тими ж групами областей, між якими було розподілено інтегральний індекс людського здоров'я. Цей розподіл представлено утаблиці 4.

Як видно із таблиці 4, у групі областей 3 хорошим здоров'ям населення індекс медичного забезпечення населення у середньому становив 0,601, з задовільним здоров'ям - 0,512, з незадовільним - 0,562. Дисперсійний аналіз показав, що ці величини суттєво між собою не від- різняються ( $F=0,56 ; p>0,05)$. Це означає, що усі групи населення областей з різними рівнями здоров'я мають приблизно однаковий рівень забезпечення медичною допомогою в її комплексі. Отже, інтегральний індекс медичного забезпечення населення повторює результати аналізу медичної забезпеченості населення її окремими вида-

ми. Це свідчить про те, що запропонований індекс медичного забезпечення населення адекватно відбиває реальність. До того ж він просто визначається, дані для його розрахунку доступні тощо. Тобто цей індекс, як і ІЛЗ, цілком відповідає вимогам ВООЗ щодо інтегрального індексу здоров'я населення.

Таблиця 4

Розподіл областей України за станом здоров'я населення за величиною індексу людського здоров'я і за групами індексу медичного забезпечення населення у цих областях, 2017 рік

\begin{tabular}{|c|c|c|}
\hline Область & $\begin{array}{c}\text { Індекс } \\
\text { людського } \\
\text { здоров'я (ІЛЗ) }\end{array}$ & $\begin{array}{c}\text { Індекс медичного } \\
\text { забезпечення } \\
\text { населення (IMЗН) }\end{array}$ \\
\hline \multicolumn{3}{|c|}{ I. Хороше здоров'я } \\
\hline Закарпатська & 0,770 & 0,247 \\
\hline Херсонська & 0,829 & 0,920 \\
\hline Чернівецька & 0,780 & 0,677 \\
\hline Сумська & 0,821 & 0,562 \\
\hline Загалом & 3,2 & 1,216 \\
\hline У середньому & 0,800 & 0,601 \\
\hline \multicolumn{3}{|c|}{ II. Задовільне здоров'я } \\
\hline Волинська & 0,673 & 0,451 \\
\hline Дніпропетровська & 0,515 & 0,491 \\
\hline Житомирська & 0,673 & 0,483 \\
\hline Вінницька & 0,519 & 0,513 \\
\hline Кіровоградська & 0,670 & 0,454 \\
\hline Львівська & 0,532 & 0,672 \\
\hline Миколаївська & 0,622 & 0,159 \\
\hline Одеська & 0,660 & 0,406 \\
\hline Полтавська & 0,702 & 0,526 \\
\hline Рівненська & 0,600 & 0,536 \\
\hline Запорізька & 0,770 & 0,510 \\
\hline Тернопільська & 0,642 & 0,656 \\
\hline Харківська & 0,705 & 0,876 \\
\hline Хмельницька & 0,590 & 0,479 \\
\hline Черкаська & 0,649 & 0,464 \\
\hline Загалом & 9,522 & 7,676 \\
\hline У середньому & 0,635 & 0,512 \\
\hline \multicolumn{3}{|c|}{ III. Незадовільне здоров'я } \\
\hline Івано-Франківська & 0,477 & 0,761 \\
\hline Чернігівська & 0,511 & 0,611 \\
\hline Київська & 0,370 & 0,313 \\
\hline Загалом & 1,358 & 1,685 \\
\hline У середньому & 0,453 & 0,562 \\
\hline $\begin{array}{l}\text { Коефіцієнт } \\
\text { достовірності F }\end{array}$ & 22,52 & 0,56 \\
\hline$p$ & $<0,01$ & $>0,05$ \\
\hline
\end{tabular}




\section{Висновки}

Наведені результати аналізу з залученням необхідних методів математичної статистики дають підстави зробити висновок: запропоновані інтегральні індекси людського здоров'я та медичного забезпечення населення адекватно відображають реальність, прості у застосуванні, і їх можна рекомендувати для впровадження у практику медичної статистики і на рівні МОЗ країни, і на рівні ВООЗ. За їхньою допомогою можна порівнювати узагальнені рівні здоров'я населення та його медичного забезпечення за окремими регіонами чи країнами.

\section{ЛІТЕРАТУРА}

1. Королев М.А. Статистический словарь. М. : Финансы и статистика, 1989. 621 с.

2. Лопатников Л.И. Краткий экономико-математический словарь. М. : Наука, 1979. $358 \mathrm{c}$.

3. Власенко, Н.І., Дучинський, Б.Н., Канаровська Л.О. та ін. (уклад). Словник термінів з первинної медико-санітарної допомоги населенню. За ред.

В.В. Загороднього,

Р.М. Макомели. К., 2000. $132 \mathrm{c}$.

4. Ціборовський О.М.

Здоров'я населення і фактори ризику, що впливають на його стан, як об'єкт управління (огляд літератури). Україна. Здоров'я нації. 2015. № 2 (34). С.13-19.

5. Бєлікова І.В., Костріков А.В. Показники здоров'я населення та сучасні погляди на методи їх розрахунку. Вісник ВДНЗУ «Українська медична стоматологічна академія». 2017. Т. 17, № 1 (57). С. 18-20.

6. Бєлікова І.В., Костріков А.В., Радченко Н.Р. Інформаційне забезпечення моніторингу стану здоров'я населення у сучасних умовах. Актуальні проблеми сучасної медицини. 2018. T. 18, № 1 (61). С. 9-13.

7. Голубчиков М.В., Орлова Н.М. Міжнародний досвід використання інтегральних показників для моніторингу та оцінки стану здоров'я населення (лекція). Україна. Здоров'я нації. 2017. № 3 (44). С. 89-94.

8. Ермаков С.П.

Моделирование процессов воспроизводства здоровья населения (научный обзор). Москва : ВНИИМИ, 1983. 69 с. 9. Україна. Людський розвиток. Звіт. К. : ПРООН, 1974. 384 с.

10. Мерков А.М., Поляков Л.Е. Санитарная статистика (пособие для врачей). Ленинград : Медицина, 1974. 384 с.

11. Заболотько В.М., Кравчук Н.Г., Стешенко І.Є. та ін. (уклад.). Показники здоров'я населення та використання ресурсів охорони здоров'я в Україні за 2016-2017 роки / Центр мед.

статистики МОЗ України.

Київ : Поліум, 2018. 327 с. REFERENCES

1. Korolev M.A.

Statisticheskiy slovar

[Statistical Dictionary].

Moscow : Finansy i statistika

;1989 : 621 p. (in Russian).

2. Lopatnikov L.I. Kratkiy ekonomiko-matematicheskiy slovar [Brief Economics and Mathematics Dictionary]. Moscow : Nauka ; 1979 :

358 p. (in Russian).

3. Vlasenko N.I., Duchynskyi B.N., Kanarovska L.O. et al. Slovnyk terminiv po pervynnii medyko-sanitarnii dopomozi naselenniu [Glossary of Terms for Primary Health Care of the Population]. Kyiv; 2000 : 132 p. (in Ukrainian).

4. Tsiborovskyi O.M. Zdorovia naselennia i faktory ryzyku, shcho vplyvaiut na yoho stan, yak obiekt upravlinnia (ohliad literatury) [Health of the Population and Risk Factors Affecting its State as an Object of Management (Literary Review)]. Ukraina. Zdorovia natsii. 2015; 2 (34) : 13-19 (in Ukrainian).

5. Bielikova I.V. and Kostrikov A.V. Pokaznyky zdorovia naselennia ta suchasni pohliady na metody yikh rozrakhunku [Population Health Indicators and Modern Views on the Methods of their Calculation].
Visnyk VDNZU «Ukrainska medychna stomatolohichna akademiia». $2017 ; 17(1 / 57)$ : 18-20

(in Ukrainian).

6. Bielikova I.V., Kostrikov A.V. and Radchenko N.R. Informatsiine zabezpechennia monitorynhu stanu zdorovia naselennia v suchasnykh umovakh [Information Support for Monitoring of the Health State of the Population under Modern Conditions]. Aktualni problemy suchasnoi medytsyny. $2018 ; 18(1 / 61)$ : 9-13 (in Ukrainian).

7. Holubchykov M.V. and Orlova N.M. Mizhnarodnyi dosvid vykorystannia intehralnykh pokaznykiv dlia monitorynhu ta otsinky stanu zdorovia naselennia (lektsiia) [International Experience in the Application of Integrated Indicators for Monitoring and Assessment of the Health State of the Population (Lecture)]. Ukraina. Zdorovia natsii. 2017 ; 3 (44) : 89-94 (in Ukrainian).

8. Ermakov S.P. Modelirovaniye protsessov vosproizvodstva zdorovia naseleniya (nauchnyy obzor) [Modeling of the Processes of Population Health Reproduction (Scientific Review)]. Moscow ; 1983 : 69 p. (in Russian).

9. Ukraina. Liudskyi rozvytok. Zvit [Ukraine. Human Development. Report]. Kyiv : PROOON ; 1974 : 384 p. (in Ukrainian).

10. Merkov A.M. and Polyakov L.E. Sanitarnaya statistika (posobiye dlya vrachey) [Sanitary Statistics (Guide for Doctors)]. Leningrad : Meditsina ; 1974 : 384 p. (in Russian).

11. Zabolotko V.M. Kravchuk N.H., Steshenko I.Ye. et al. Pokaznyky zdorovia naselennia ta vykorystannia resursiv okhorony zdorovia $v$ Ukraini za 2016-2017 roky / Tsentr medychnoi statystyky MOZ Ukrainy [Health Indicators of the Population and Use of Health Resources in Ukraine for 2016-2017 / Center for Medical Statistics of Ukraine]. Kyiv : Polium ; 2018 : 327 p. (in Ukrainian).

Надійшло до редакції 21.10.2020 